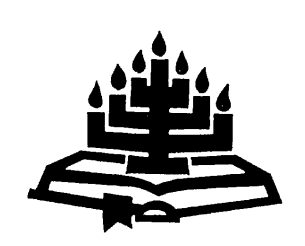

\title{
The Gospel of Matthew and women
}

\author{
P.J.J. Botha \\ Department of New Testament \\ University of South Africa \\ PRETORIA \\ E-mail: bothapjj@unisa.ac.za
}

\begin{abstract}
The Gospel of Matthew and women

Matthew obviously reveals no concern with gender roles and issues about female leadership. This Gospel simply perceives such issues from the perspective of conventional patriarchal terms within the Roman household ideology, at best believing "collegiality" to be proper for his community. In order to avoid biblicistic and/or fundamentalistic theological reflection these issues should be acknowledged in our "wrestling" with Scripture. At the same time Matthew's vision of God and the abundant righteousness demanded allow us to go beyond Matthew's treatment of women and radicalise not only the implicit call to equity in our tradition but even our own context's emphasis on equality.
\end{abstract}

\section{Opsomming}

Die Evangelie van Matteus en vroue

Matteus is nie geïnteresseerd in geslagsrolle of vrae rondom vroue se leierskap nie. Hierdie Evangelie beskou sulke sake vanuit die perspektief van aanvaarde patriargale waardes binne die Romeinse huishoudingsideologie, en is, simpatiek beoordeel, waarskynlik 'n voorstander van "kollegialiteit", as norm vir sy gemeenskap. Om biblisistiese en/of fundamentalistiese teologisering te vermy moet hierdie aspek erken word wanneer daar met die Skrif "geworstel" word. Tegelykertyd dwing Matteus se Godsopvatting en die oorvloedige geregtigheid wat vereis word, ons om verder as Matteus se beskrywing van vroue te gaan en nie net die implisiete oproep tot gelyke beoordeling in ons tradisie te radikaliseer nie, maar selfs die hedendaagse beklemtoning van gelykheid. 


\section{Perspectives}

Traditionally, the Gospel of Matthew is not associated with the struggle surrounding women's leadership roles and gender issues. That honour is usually ascribed to the Gospel of Luke ${ }^{\mathbf{1}}$ and Paul ${ }^{2}$. Of course, women are prominent in Matthew, and scholarship has not neglected this topic. Predictably, the fact that, with the exception of Jesus' family in 12:46-50 and Herodias and her daughter in 14:1-12, women are portrayed "positively" by Matthew, has led to claims that we find in Matthew criticism of patriarchal structures and indications of equality for women.

Anderson (1983) reads the Gospel of Matthew in terms of feminist literary criticism; she analyses the symbolic significance of gender in the gospel and emphasises the role of the implied reader. She finds that there is "a tension between the treatment of female gender as a positive attribute or irrelevant in comparison to other values and its treatment as a mark of subordinate status" (Anderson, 1983:21). She sees Matthew giving women "important roles" and therefore the narrative strains "the boundaries of the gospel's patriarchal worldview" (Anderson, 1983:21). "Yet female gender renders the exemplary behavior of women as more of an achievement and heightens contrasts with male characters" (Anderson, 1983:21, my emphasis - PJJB).

In a redaction-critical study, Selvidge (1984) understands the Matthean community as one challenged by the effects of a violent war and the intrusion of peoples who come from a variety of backgrounds. Within this setting of violent activities and abusive traditions, Matthew sees a future for the community if they recognise the strength in the examples of some (women) without ignoring the potential violence in all. "Women emerge as solidifying agents within this new community. They are part of the reason for its existence and continuation" (Selvidge, 1984:220).

A questionable honour, relying on a problematic reading of Luke-Acts. Davies (1991:185-190) shows that it is an assumption that Luke-Acts advocates raising the social status of women, and not the text itself. It is doubtful whether "... Luke can be shown either to have been intent on presenting Jesus as particularly sympathetic to women or to have encouraged the liberation of women in any signficant sense" (Davies, 1991:185). Schüssler Fiorenza (1983:49, 160-162) discusses the Lukan redactional tendency to delimit women's roles in early Christianity, which prompts Schaberg (1992:275) to sharply warn against the use of Luke with regard to gender issues.

2 Paul, at least, makes a dramatic claim with regard to male and female (Gal. 3:28). As is well-known, that statement is relativised by other Pauline statements. Cf. Botha (2000:27-28). 
Kopas points out that it is fair to conclude that Matthew expresses a cautious and traditional view of women who have little importance in the church or the life of Jesus. However, "a closer examination of the roles they do play reveals a somewhat more complex picture" (Kopas, 1990:13). One needs to be careful not to idealise the women in the Gospels, she warns (Kopas, 1990:21), but contends that Matthew draws a picture in which he struggles "to incorporate women moving from the periphery to greater public involvement and from being victims and survivors to being disciples and leaders" (Kopas, 1990:13).

In contrast, Stuart Love (1993:22) maintains that Matthew

... presupposes a rigid, hierarchical, authority-centered social structure largely based on the paradigm of the household. Although exceptional or deviant gender behavior exists, it does not burst the societal boundaries of the household determined by an advanced agrarian mould.

Consideration of Matthew and women raises several exegetical questions. In the rest of the article I will establish the basics of the Matthean data by means of a close reading and then contextualise the Matthean narrator's depiction of women in order to draw some critical conclusions with regard to this Gospel (and Scripture), gender and faith.

The focus and limitations of this article should be noted. There can be no doubt that women followed Jesus, or that women played an important part in the development of early Christianity (cf. e.g., Batten, 1994; Reinhartz, 1991; Schottroff, 1993; Schüssler Fiorenza, 1979; 1993; 1994). In this article, I concentrate on the Gospel of Matthew (and not the historical Jesus) and discuss questions raised by this text as part of Christian Scripture. I am quite sure that women followers of Jesus were far more important and active than Matthew is letting on, and that their experiences enabled them to contribute to the development of the early Jesus movement in unique ways, but those questions are not dealt with here.

Methodology is also at stake. For this article my interest is not an explicit liberation hermeneutics - which, it must be emphasised, must be practised not only because it is important, valid and relevant, but because it is right - and am not seeking liberatory motifs at all costs in this Gospel, but want to "listen" to Matthew. If the text does not say what I want it to say, it is best to acknowledge that and deal with it accordingly. If one cannot respect the otherness of Matthew, how can I (how dare I?) even dream of respecting my own contemporaries, and claim gender freedom as the unfulfilled ethical objective for life and living? 


\section{Women in Matthew}

Matthew reflects norms and values about and attitudes toward women because the narrator and the main characters in the story speak about women, and women appear as characters in the narrative. Although several passages are relevant to illustrate this Gospel's perceptions, I will concentrate on the following: Jesus' genealogy (1:1-17), two depictions of the faith and initiative of women (9:20-22; 15:21-28), and various passion and resurrection scenes involving women (26:6-13; $27: 55-56 ; 27: 61 ; 28: 1-10)$.

\subsection{Matthew 1:1-17}

Matthew 1:1 clearly functions as superscription to the first section, and with the genealogy sets the stage for reading the rest of the Gospel. The heading introduces Jesus as Christ, son of Abraham and son of David. The narrative gives meaning and contents to these concepts. "Jesus" is explained almost immediately (in 1:214) but the whole narrative is an "exposition" of these names. By the end of the narrative, the audience knows that these illustrious Israelite titles have a very specific connotation, that this saviour (Jesus), this leader and king of Israel is actually the king and leader of followers from all the nations (28:18-20). "The old conviction of the divine presence in Israel (particularly the temple) is here transformed into belief in Christ's presence in the true Israel" (Gerhardsson, 1974:31). The "peculiarities" of the genealogy is an anticipation of that conviction, just as the conclusion of the gospel is a confirmation of those suggestions right at the beginning.

The genealogy substantiates Jesus' patrilineal claim to these titles. The

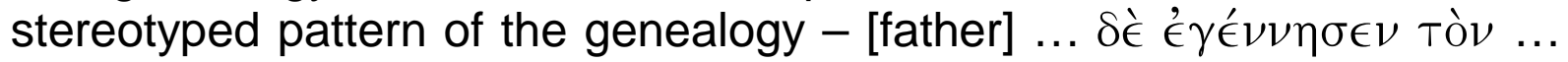
[son] - repeats itself 39 times, hence the four breaks in this pattern is not only noteworthy but highly significant. 5 Several interpretations have been offered for the peculiar introduction of women into the Matthean genealogy, conveniently summarised by Brown (1977:71-74):

3 Brown (1977:133-143) provides a useful discussion of the who (quis) and how (quomodo) of Jesus' identity in terms of the "titles".

4 As the audience of this gospel encounters this name more than 150 times after the "title"/super-script of Matthew 1:1, the audience "recalls this statement of Jesus' role and observes how and if Jesus carries out the task. Around this name cluster the traits which the audience identifies through the narrative" (Carter, 1996:191-192). 
- the women were regarded as sinners, hence their inclusion foreshadows the saving of sinful humanity;

- the women were regarded as foreigners and were included to show that Jesus, the Jewish Messiah, was related by ancestry to Gentiles;

- these women point to Mary as there is something extraordinary in their union with their partners and they played important roles in God's providence.

Most modern commentators opt for the third alternative (including Brown himself), preferring to see special status being accorded to Mary by Matthew, not only in 1:18-25, but also by the prefigurement of the women in the genealogy.

The difficulty is that in Matthew Mary plays an insignificant role (we should not read Matthew through Luke's lenses). The author refers to Jesus' mother five times by name $(1: 16,18,20 ; 2: 11 ; 13: 55)$, and a further three times as simply "the child and his mother" $(2: 13,14,20,21)$. Not once is she an active subject; she does not speak nor is she spoken to. She is in a most literal sense just background.

It is only by a stretch of imagination that an exalted role for Mary can be detected here. In Matthew Joseph is the one focused on: it is to him that the angel of God speaks, it is his status and honour that is discussed, he names the child and acts according to God's instructions. It is he who takes the child "with Mary his mother" to Egypt. For Matthew, Mary is only mentioned because she gives birth to the child to be called Jesus. Matthew tells us that this son (vióv, 1:23) is conceived of the Holy Spirit, will be "Immanuel" and that his father, Joseph, is a righteous man

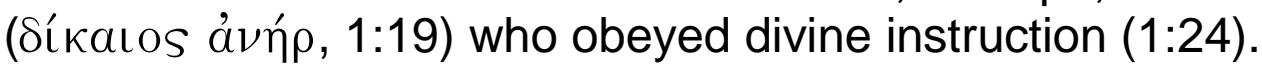

The best explanation for the fourfold interruption in the genealogy - and in fact the only one really supported by the text and narrative context - is the fact that these women are foreigners. Matthew expects of his intended audience to be familiar with Old Testament detail: Rahab and Tamar were Canaanites, Ruth was a Moabite and Bathsheba was the wife of Uriah the Hittite (note the way that Bathseba is referred to, 1:6) ${ }^{6}$. These women function in anticipation of and introduction to what "real" Israel is about: according to Matthew that entails Gentiles becoming disciples of Jesus (cf. Carter, 1996:121-123). Matthew's concern is not the gender (or the actions) of the women but to illustrate that God's people have a "new" definition for being "sons" of Abraham, "people who, though not Jews, were like Jesus in their descent from Abraham"

6 It is noteworthy that these women feature quite positively in post-biblical Judaism; see Brown (1977:72-73) for references. The focus is not on their being "sinners". 
(Brown, 1977:74). Like Matthew 28:19-20 is the fulfilment of the promise made to Abraham, so is the genealogy a clarification of that promise. ${ }^{7}$

\subsection{Women showing faith and initiative}

The woman with the hemorrhage (9:20-22) and the Canaanite woman $(15: 21-28)$ play noteworthy roles in the Matthean narrative. Both are supplicants and members of "outsider" groups: the first is ritually unclean (or a "sinner" - note the context: Jesus associates with tax collectors and sinners, 9:10-11; Jesus came to call sinners, 9.13) and the second is a Gentile. The way they are introduced underscores their parallel roles in the gospel:

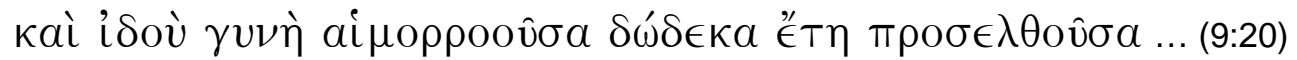

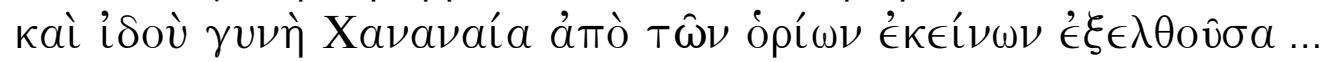
$(15: 22)$

Both women exhibit faith and initiative in their approaching of Jesus. We should, however, pay careful attention to what Matthew emphasises. The Matthean Jesus highlights their faith in order to make the point that God's Christ cares for the "harassed and helpless", the "sheep without a shepherd" (9:36), the "lost sheep of the house of Israel" (15:24). Matthew's proclamation of Jesus ("who will save his people", 1:21) is also a redefinition of "Israel". 8 In Matthew's narrative these two women are first and foremost like other outcasts (from a traditional/conventional Israelite point of view): the blind, the lepers, "these little ones" (18:14), those who need the doctor (9:12), and so on.

The healing/saving ( $\sigma \epsilon^{\prime} \sigma \omega \kappa \kappa^{\prime} \nu, \dot{\epsilon} \sigma \omega \dot{\theta} \theta \eta, 9: 22$ ) of the hemorrhaging woman is intercalated between a ruler's request for and the healing of his daughter. The narrative then continues with the healing of two blind men. In the whole section (Matt. 9) the opposition between Jesus and the Jewish leaders figures strongly. Jesus' and his disciples' violation of the accepted norms are challenged: Jesus responds by healing those left out by those norms, confirming the validity of his "violation" and challenging

On Abraham in Matthew: Matthew 3:9 and 8:1-12 are particularly striking clues to the author's thinking.

8 Matthew's narrative is also a vision for Israel. Though this vision (and related aspects) of the Gospel of Matthew is widely recognised, its centrality to the evangelist's message must be emphasised. His narrative is, to repeat, in its proclamation of Jesus Christ also a stunning vision of Israel, the people of God. Its profound Gentile bias functions within the perspective of Israel. See, esp., Gaston (1975); Loader (1982), who discusses how Matthew contrasts "blind" Israel with those who chose through Jesus to see; and the valuable studies by Danker (1994) and Saldarini (1994:27-43, 165-193). 
the scribes and Pharisees living according to those norms. The faith of the supplicants contrasts with the reactions of the Jewish leaders (9:1-8). The leaders think Jesus blasphemes by forgiving sins (9:3), the crowds fear and glorify God "who gives such authority to men" (9:8) and the supplicants show true faith $(9: 2,22,28)$.

The healing stories (Matt. 8-9) as a section concludes with an exclamation: "Never was anything like this seen in Israel" (9:33). Precisely: for Matthew it is in Israel that the true son of David heals and saves the outcasts. Not just a new piece of cloth to fix an old garment; not just new wine, but new wine in new skins (9:16-17). These Matthean healing stories reveal faith as taking seriously the implication of "Godwith-us" (Luz, 1995:68-70). Consequently, the focus in 9:20-22 is not on the woman's faith, but on the woman's faith, which contrasts with the leaders' lack of faith and their commitment to "blinding" conventions.

Matthew is "exploding" boundaries of acceptable association here (as claimed by Anderson, 1983:12), but he does that by exploding concepts of the son of David. Note that the son of David in Matthew is particularly mentioned in healing stories, and the Matthean image of the son of David "is not a story of wars and acts of political liberation, but one of healings and love" (Luz, 1995:71).

If the title 'Son of David' is heard time and again in connection with miracles, if he is addressed as 'Son of David' by a Gentile woman and by the uneducated, but not by the Pharisees, the readers of Matthew's Gospel are given to understand that this is a Son of David of a quite particular kind. He is a liberator of simple people, a liberator from disease and material want (Luz, 1995:71).

Matthew does not mention the oppression of the woman nor her social liberation. The author is concerned with explaining Jesus, that "He took away our illnesses and carried off our diseases" (Matt. 8:17). When it comes to equal discipleship for women according to Matthew, the best one can do today is to point to a possible consequence of Matthew's teaching about Jesus' healings, a logical conclusion that others might draw (and which we should draw) but one not designed by Matthew.

This is confirmed by the interaction between Jesus and the Canaanite woman (15:21-28). Jesus responds to her request by verbally echoing his restriction of the disciples' mission (10:6): "I was sent only to the lost sheep of the house of Israel" (15:24). Yes, she agrees, but then reveals that faith in Jesus, that is confessing Him as son of David, as Lord, gives access to the crumbs. It is not just Jesus' requirements that she 
overcomes with her faith. Matthew's concern is not - as with Mark ${ }^{9}$ - the sequence of salvation (first Israel then Gentiles), but that the fundamental difference separating Israel and the Gentiles be overcome. This scene forms a link in a very important narrative chain of indications, such as comments from the narrator $(4: 14-16 ; 12: 18-21)$ and other scenes such as the Magi (2:1-2) and the Roman centurion (8:5-13). Matthew is unambiguously anticipating and justifying the Great Commission of 28:19-20. In fact, a number of doublets in Matthew's narrative enhances this crucial aspect of the healing of the Canaanite's daughter:
A Two blind men
"Have mercy on us, son of $(9: 27-31 ; 27)$ David"
B Sign of Jonah
C Feeding of 5000
$\square$ Canaanite woman
"Have mercy on me Lord, son of
$(15: 22-28 ; 22)$ David"
$\mathrm{C}^{\circ}$ Feeding of 4000
$\mathrm{B}^{\circ}$ Sign of Jonah
$A^{\circ} \quad$ Two blind men
"Lord, have mercy on us, son of David"
(20:29-34; 30)

Through these repetitions Matthew develops his "christology": the authority and identity of Jesus. The narrator carefully contrasts those who trust that Jesus (who is greater than David, Jonah or Solomo, 12:2142; 22:41-45) can heal with those who do not believe, do not see and seek a sign and are stuck with the yeast of the Pharisees and Sadducees (16:5-12). Jesus truly gives bread, superabundantly; and his activities - healing and teaching - are, for Matthew, the kingdom of God (cf. 4:23). And that, after all, is what the Davidic title is about: the kingdom of God. Once again, Matthew is clearly leading his audience to "see" what faith is about; viz. to see "through" Jesus: the what and how of the real son of David - and what faith is not, namely looking for the signs sought by the Jewish leaders.

9 Note that according to Mark Jesus says that Israel be "first" to partake of salvation:

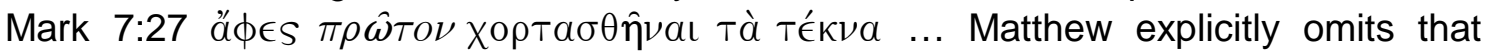
$\pi \rho \hat{\omega} \mathrm{To \nu}$. 
The two women do not reappear in the narrative. They are not depicted as disciples nor as illustrative of discipleship. The narrator uses their interaction with Jesus to explain Jesus. Jesus is the messiah (the one sent/chosen by God) to heal the outcast. The women are foils for other characters. They are like the Roman centurion in 27:54, who says the right thing, but is not in himself of any importance to the author of the gospel. 10 Disciples can and should learn from these women what faith is, but Matthew (unintentionally?) misses the implication of gender equality and discipleship completely. It simply does not exist for him. In a very real sense, the Matthean narrator represents a form of thinking preceding (or denying) the debate about women as actual church leaders.

\subsection{The women at Bethany, the cross and tomb}

An unnamed woman anoints Jesus at Bethany (Matt. 26:6-13). Mark explicitly contrasts her with the women going to the empty tomb, thereby making her into the first actual witness, and thus also the first real disciple. In Matthew, however, the account begins with $\delta \epsilon$, establishing a contrast between the preceding account of the Sanhedrin conspiring

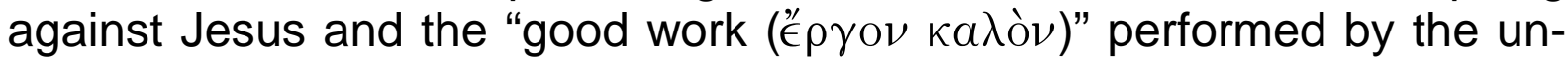
named woman. The contrast becomes sharper when Judas Iscariot accepts thirty silver coins (in Mark, it is just "money"): she gives away "a large amount", an "expensive" gift. Matthew's point is obviously that when the Son of man is handed over to be crucified two reactions will be evident, that of the chief priests and elders (26:3-5, rejection) and Judas' (26:23-25, betrayal) or the reaction of the unnamed woman. As at the beginning of the story $(2: 11)$, also towards the end: lavish gifts are bestowed on Jesus. These gifts are to worship Jesus and acknowledge Him as the One sent by God.

In Matthew 26-28 we must note the emphases that the narrator is placing, in particular the prophetic knowledge of Jesus, his dominance over the events of the passion, his status as Son of God, Son of man, messiah and king (cf. Senior, 1975). "All these elements underscore the centrality of the person of Jesus. ... All other theological perspectives in the passion narrative must be understood from this central Christological perspective" (Meier, 1979:180).

With regard to the women at the cross and the tomb it is noticeable that Matthew depicts them far more positively than Mark. Yet, and therefore even more striking, these women are not depicted as disciples by

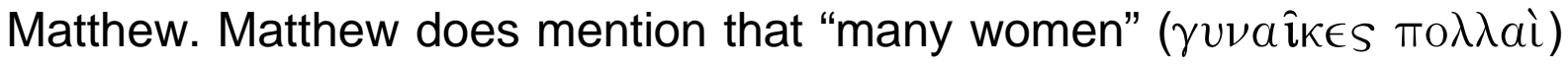

10 'One might add that the supplicants' function as foils would be limited if they became disciples" (Anderson, 1983:17). 


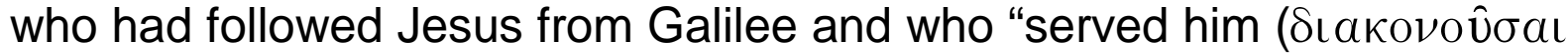

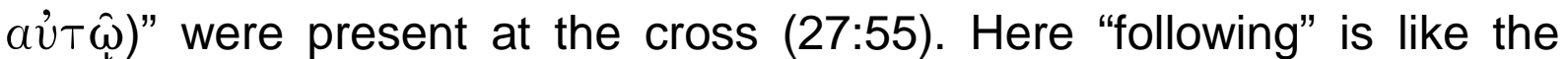
large crowds following Jesus to the other side of the Jordan (19:2; note

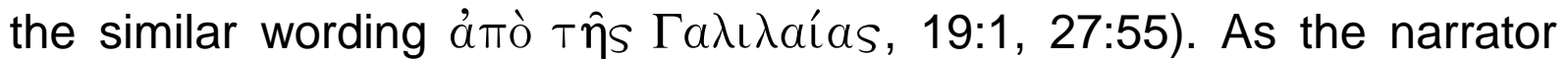
describes the women, their activity is not related to commitment and cost. The relevance of the women for the plot is determined by "serving"

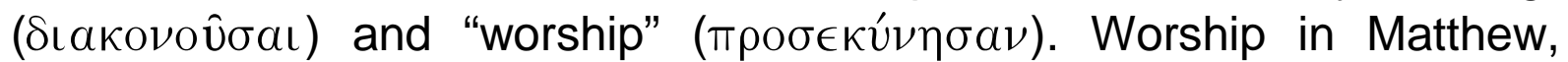
incidentally, though it is the proper attitude toward Jesus (cf. Anderson, $1983: 16$ n. 35), can and often does include doubt - it is a characteristic of "little faith" (cf. 28:17; 8:26; 14:31; 16:8; 17:20).

"Serving" Jesus is not yet discipleship. "The appended notation that they were 'waiting on him' is not meant to characterize them as disciples of Jesus in the strict sense of the word but instead explains why they had been in his company" (Kingsbury, 1978:61). In 4:11 the angels minister to Jesus, and in 8:15 Peter's mother-in-law ministers to Jesus after he has cured her fever. The women are "serving" Jesus - doing what women do when in the "family" or in the house. They are not disciples.

In Matthew these women function as links. The women and their actions constitute "bridging scenes" to make his plot work. That is how Matthew tells his story (which must be distinguished from historical events). One of the three women named in 27:56 is identified as the mother of the sons of Zebedee. Though she accompanies the twelve on the way to Jerusalem (20:20) she is not privy to the private instruction given to the twelve. The role of this mother is to request places of honour for her sons - which provides the Matthean Jesus an opportunity to explain to the disciples that they know not what they are asking (note the plurals:

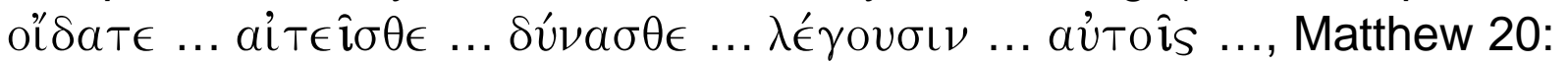
22-23).

Most telling are the references to "the disciples" after the resurrection. The women are clearly distinguished from the disciples. The two Marys are commanded to "tell his disciples" about Jesus' resurrection and appearance in Galilee (28:7). Matthew then describes the women running to tell "his disciples" (28:8). Jesus himself commands the women to "tell my brothers to go to Galilee" (28:10). The women obey and the "eleven disciples" go to Galilee (28:16). The women are not outsiders or strangers, but are not among the circle of disciples either. They are servants, and they worship Jesus, but they are not disciples.

The parable of the foolish and wise young women (Matt. 25:1-13), unique to Matthew, is a typical reflection of his reference to female characters - women depict attitudes toward Jesus. Women in Matthew's 
story of Jesus are representations of faith (or lack of faith) and thereby illustrations of Matthew's actual concerns. Matthew simply does not see the "problem" of women disciples.

\section{Socio-cultural context and ideology in Matthew}

The textual analysis can only be useful when contextualised.

\subsection{Household ideology}

The Gospel of Matthew reflects the household ideology characteristic of the first-century Roman/Mediterranean world (Elliott, 1981:170-182; Garnsey \& Saller, 1987:126-147; Judge, 1960:30-39; Verner, 1983:2782 ) - it would have been truly remarkable if it did not, and then would probably have been incomprehensible to its contemporaries. It is, after all, a document from an advanced agrarian society.

As is to be expected of a text from such a context, the household functions as metaphor for social units: kingdom, nation, city, village, and family. Hierarchy characterises all these units, as it does the household. The imagery used to illustrate the kingdom (whether of heaven or earthly) is consistently household imagery: a master, servants, sitting at table, sons, a father, householder, children.

Note Jesus' parables in which several household examples are found. In the parable of the unforgiving servant, the status of a slave, with his wife and children, is described as property (18:21-34). The parable of the labourers in the vineyard $(20: 1-16)$ refers to a male householder who hires labourers for his vineyard. The parable of the two sons $(21: 28-32)$ assumes the greater/lesser status of being either the first or second son with a parallel drawn to the religious leaders and the tax collectors and harlots. In the parable of the wicked tenants (21:33-46), a householder plants a vineyard and lets it out to tenants who harm and kill the male servants and, eventually, the son. In the parable of the marriage feast (22:1-14), all the characters are male: a king, his son, the servants, the attendants and the one removed from the feast for not having a wedding garment (22:11). If the householder had known when the thief was coming, he would have watched (24:42-44). A faithful and wise male servant is placed over his master's household to provide for the servants' needs (24:45-51). In the parable of the talents (25:14-30), a man goes on a journey and entrusts his property to male servants who engage in business for the purpose of making a profit for their master.

The property status of wives is visible in such phrases as "his wife" or its equivalent $(5: 31,32 ; 18: 25 ; 19: 3,5,7,9 ; 1: 24 ; 14: 3 ; 22: 25 ; 27: 19)$. 
Passages on divorce $(5: 31-32 ; 19: 3-12)$ assume that divorce is a male privilege and that wives belong to their husbands. ${ }^{11}$

Household imagery informs the language and ideas describing both the kingdom of heaven and the kingdom of Satan. Beelzebul is called "master of the house", and those who serve him belong to "his house" $(10: 25)$. Satan's kingdom is a house (12:25-29) which can be plundered only if the strong man of the house is first bound. In the kingdom of heaven, Gentiles are included as they "sit at table" with Abraham, Isaac, and Jacob, while "the sons of the kingdom" will be thrown into outer darkness $(8: 11,12)$. In the parable discourse $(13: 1-52)$ the "good seed" sown by the sower is a metaphor for the "sons of the kingdom" (13:38); the righteous are said to shine like the sun in the kingdom of their Father (13:43). Jesus teaches his disciples that every scribe "who has been trained for the kingdom of heaven" is like a "householder who brings out of his treasure what is new and what is old" (13:52). In other settings, the kingdom is likened to a king who "settles accounts with his servants" (18:23).

This extensive set of imagery reflects the social realities of households in an agrarian culture. In Matthew we find a natural assumption that the household, as the social structural foundation for the kingdom, nation, city, village, and family should function as metaphor for his central theme, the reign of God. The pervasive position of the ancient household and its hierarchical values in this Gospel cannot be doubted; it represents to the Matthean narrator a familial/political metaphor which cuts across the society from the oikos to the polis. It provides almost all of the significant images used by Jesus in his teachings concerning the kingdom and discipleship. The household depicts both a social reality and provides social imagery. The household ideology of the master, his power and his family, belongings and heritage are manifest in a variety of details of the narrative's symbolic universe.

\subsection{Gender roles}

The Matthean gospel operates with a symbolic universe that is androcentric and encodes the patriarchal constructs present in its sociohistorical location. The textual world is one in which the male norm is what is human, and this perspective finds expression in the grammatical and narrative strategies of the text. In the Sermon on the Mount, for instance, the repeated use of terms such as son(s), man, men, brother,

11 Jesus' teachings on divorce elicits a typical male response from the disciples: then 'it is not expedient to marry" (19:10 - i.e., their assumption is that men cannot but commit adultery). 
father and he $(5: 13,15,19,22,45 ; 6: 1,16,18 ; 7: 3-5,8,9,12,21)$ represents a narrative world from which women are absent. The experience of sonship, fatherhood and brotherhood is considered universal and hence adequate for the expression of human experience.

Throughout, the illustrative imagery is androcentric. To remain with Mattew 5-7: the ancestors are "the men of old", it is a man who is angry with his brother, the recipients of the teachings are constructed as male (e.g., 5:28, 31-32), it is a brother that is greeted (5:47). Only once does Matthew refer to sisters (12:50) and then the point is about doing the will of the Father, in contrast to blood connections (12:45).

In the Matthean narrative world, women are "flat" characters. With regard to gender roles, the cultural characteristic of the social bodies of women, nothing remarkable is reported by the narrator.12 Women are mostly silent, and spoken to. When they do speak, they ask basic questions, illustrative of the narrator's concerns. Some are shown in a positive light (as faithful "daughters" of Israel), many are spoken about in neutral terms, and some women act foolishly. In Matthew women typically are mothers, they serve (Jesus and other men), they worship and they carry messages. Even when Matthew does expand on the presence of women in a positive sense, "women's role of deficiency or dependence is not overcome but is used to challenge others to meet their needs and at the same time to learn humility and faith from them" (Wire, 1991:106).

The narrator simply is not interested in gynocentric proclivities but in Jesus' mission to teach, preach the gospel of the kingdom and to heal (4:23); in Jesus sending his (male) disciples, when he is given all authority in heaven and on earth, to the nations (28:18-20). Jesus' relationship to women is never shown to be thought odd by anyone. Judging by the fact that none of the characters in the gospel takes Jesus' actions toward women to be out of the ordinary, one cannot argue that Matthew sought to show that Jesus had an extraordinarily positive attitude toward women.

The author is not interested in the female characters for their own sake but, rather, uses them to enhance Jesus' significance. Women characters are demeaned by truncated accounts of their words, thoughts and deeds; they lose powerful character traits and are used by the narrator as scenery, props or rhetorical strategy. The gender inflection of

12 A comprehensive list of references to women in Matthew: 1:18-25; $2: 13,19-21 ; 12: 46-$ 50; 13:53-58; 8:14-17; 9:18-19, 23-26; 9:20-22; 14:1-12; 14:21; 15:38; 15:21-28; 20:20; $27: 55-56,61 ; 26: 6-13 ; 27: 19 ; 27: 55-56 ; 28: 1-10$. 
the Matthean text is implicitly and explicitly male and it reflects a symbolic universe characterised by this androcentric bias.

\section{Hierarchical authority and Matthew}

The remarkable fact is that Matthew does criticise aspects of patriarchy among the disciples, and in various ways suggests some alternatives to conventional societal structures.

\subsection{Unnatural authority}

The Matthean Jesus opposes leadership authority (20:25) which "lords it" over others in the church. Instead, he advocates a reverse leadership paradigm based on the servant model of the Son of man (20:28). This paradigm, consistent with the passion predictions (16:21-23; 17:22, 23; $20: 17-19)$ and the teaching on discipleship (10:24-25; 11:29), stands in contrast to the leadership paradigm reflected in the request by the mother of the sons of Zebedee (20:21), typical of the ideology characteristic of first-century Roman society.

The paradigm reversal is also illustrated when Jesus places a child (a subordinate and inferior member in the family) in the midst of the disciples (18:4) as his answer to the question "Who is the greatest in the kingdom of heaven?" (18:1). The metaphor then is carried forward to the "little ones" (18:6, 10, 14; cf. 10:42) in the church. The truths of the kingdom are hidden from "the wise and understanding" (the greater) and revealed to "babes" (the lesser) (11:25). In contrast to the Jewish religious leaders the disciples are not to be called rabbi, father, or master since they have one teacher, Jesus (23:8), one Father who is in heaven (23:9), and one master who is Christ (23:10). Greatness is modelled by servanthood (23:11), and Jesus warns the disciples that whoever exalts himself will be humbled and whoever humbles himself will be exalted (23:12). The Matthean community, called through baptism to follow Jesus, is to be a brotherhood of the sons of God $(5: 9,45 ; 13: 38 ; 12: 49$ $59 ; 18: 35 ; 23: 8 ; 25: 40 ; 28: 10)$.

Matthew includes in his story about Jesus some fundamental changes to the self-definition and understanding of the people of God: redefining Israel as "true" Israel, rethinking the covenant as something based on righteousness and love, reversing aspects of hierarchy and power. These impulses should be viewed in light of the social reality of the household and androcentrism depicted in the Gospel. 


\subsection{Collegiality?}

Given the indications discussed, there must have been an awareness (if not the practice) of collegiality among the members of the Matthean community. The calibre of this collegial attitude must be tested. Is Kingsbury (1977:105) correct when he states about the church of Matthew that, "Groups within the community can be distinguished, but hierarchical tendencies are to be resisted"? Does the incongruent evidence mean that Crosby (1988:104-110) is correct when he views this collegial possibility as a complete break with "patriarchy" and a movement toward equality?

It is probably the case that the Matthean church members believed themselves to be collegial in structure, especially among male members. Towards women that attitude probably entailed "positive acceptance". Collegiality was not uncommon among the early Christians (Crosby, 1988:30-31, 104-115; Judge, 1960:30-39; MacMullen, 1974:132-135; Malherbe, 1983:60-91; Wilken, 1971). However, and as all these studies affirm, most Christian communities were still modelled after the oikos. "In its various social, economic and religious capacities, the household served the [Christian] movement as both an opportunity and a model for organization, mobilization and proclamation" (Elliott, 1981:188). And that resulted in a very specific outcome:

Within the household the roles, relationships and responsibilities of its various members - husbands, wives, parents, children, masters, slaves, the married, the unmarried or widowed, the elder, the younger, the heads of the household and their subordinates - are exemplified through the use of traditional patterns of household conduct, the so-called Haustafeln or 'household codes' ... It is also likely that the household structure of authority influenced not only the roles but also the eligibility for leadership in the Christian community, especially at the local level (Elliott, 1981:189).

Elliott (1981:190) does note that in some early Christian households women were responsible for functions relating to management and leadership functions. In contrast to such communities, the Matthean narrative affirms the clear implication of Elliott's conclusion: the basic social organisational household and gender boundaries of Matthew's community remained intact. The evidence indicates that even though the two actualities - patriarchal/androcentric household norms and the Matthean exceptions - seem to stand in tension, the exceptions are fitted into/subsumed by convention. It would be misconstruing Matthew to understand this tension as reciprocal (as claimed by Anderson, 1983:21).

To support this contention the following: 
- The weight of the evidence already described: the androcentric register of Matthew's language and the use of household metaphors for theology and ethics.

- With the exception of Jesus none of the characters in the narrative step outside conventional gender roles and status.

- Only some manifestations of the patriarchal ideology is questioned by Matthew, and his critique is in terms of direction, not in fundamental terms. Put differently: the disciples are instructed not to lord over others like "them", but they are not told to not lord at all.

- Exaltation over others is not acceptable in the Matthean perspective, yet hierarchical authority language is used by Jesus in reference to himself, his mission, and the role of the disciples.

- Crosby (1988:97) is probably right when he argues that two "types" of house churches existed in the Matthean milieu: "specific house churches exhibited patriarchal forms while others reflected the collegia or more egalitarian model". There probably was indeed a shift of emphasis in the use of the term authority ( ${ }^{\prime} \xi \xi_{\text {ov }}{ }^{\prime} \alpha$ ) by the historical Jesus. The question is simply whether Matthew portrays Jesus' followers shifting their attitudes similarly. According to Matthew, Jesus' teaching does not eliminate a hierarchically ordered and gender structured community. Jesus' disciples receive remarkable authority (e.g., 16:19; 18:18). The disciples' reward for having left all for the kingdom of God is portrayed in a scene in which the Son of man sits on his glorious throne and those who followed him "sit on twelve thrones, judging the twelve tribes of Israel" (19:28). In Matthew Jesus uses language emphasising over-under ordered authority to teach his disciples about himself (28:18), the mission of his disciples, and the future of his followers.

- According to Matthew Jesus indicts the leadership of the scribes and Pharisees (cf. Matt. 23), but he does not criticise the household and its hierarchical structure (note, for example, the story of the centurion, 8:5-13). His criticism appears to be directed not against the social structural values germane to Greco-Roman society, but against inconsistencies and false righteousness in socio-religious ideology and practice. The concern of the Matthean Jesus is not with a hierarchical social organisation, but with titles, rank, and offices leading to an authoritarian dominance in contrast to servant leadership and theology. To equate servant leadership with equality may be logical to post-enlightenment thinking, but it fails to acknowledge the historical context of antiquity. A sociological reversal paradigm should not be confused with an egalitarian levelling. Reading egalitarianism 
into Matthew is the result of a culturally insensitive reading (cf. Craffert, 1996; 2001a; 2001b).

- Several examples in the Gospel support a tension between the two actualities of androcentric hierarchy and social reversal. Joseph

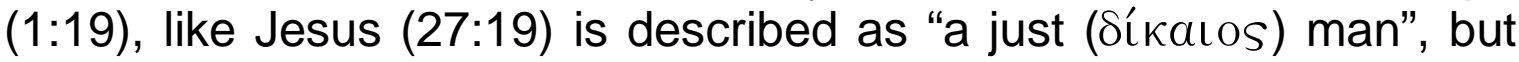
he is still depicted as a conventional household head. Jesus upholds the dignity of women when he opposes the behaviour of men and husbands $(5: 28,32 ; 19: 3-9)$, but in so doing he is portrayed as accepting the subordinate status and domestic roles of women and wives. When Jesus affirms the new family of God to be those who do the will of God, he points to his disciples, an all male group, as he exclaims, "Here are my mother and my brothers!" (12:49). The Son of man is both, and simultaneously so, the one that associates himself with "the least of these my brothers" (25:40) and the King who sits on his throne $(25: 40 ; 31)$. Community discipline involves only the male members of the community (18:15-16). In the church "all ... are brothers" (23:8), a generic reference to be sure, but the principal groups involved in the public confrontation are explicitly male - the disciples, the scribes and the Pharisees.

- Matthew reveals remarkably few specifics about actual social conditions of his church(es), and one may suspect that his very silence is significant. In any case, he did not consider gender equality of enough importance to relate it explicitly to his central concerns.

The net result of the textual data is an image not of a reciprocal tension between patriarchal and egalitarian impulses, but a definite incorporation of equity into conventional social norms.

\subsection{Attenuated patriarchy}

So the real challenge emerges: to admit that although Matthew is in many ways radical and subversive, and even though he (probably) wants to act towards women in a fair, kind and decent manner, they are still to be subordinate. Matthew is, with regard to women, everything but radical.

In a strange sense, this aspect of Matthew carries remarkable relevance. So much of being a member of a church and "good Christian values" are exactly that: to be very tolerant, decent, supposedly non-abusive (from a male point of view) et cetera, yet an attitude that does not even perceive the fundamental challenge of complete, real, and actual gender freedom, and empowered gender equality. 
Reading Matthew honestly confronts us with the reality of "attenuated patriarchy". That is, though there is ostensible denial of such practices the factual situation is still that of gender inequality. To be good (in the sense of compassionate) and conventional (in terms of acceptable behaviour) easily and smoothly become part of the life of the disciple so much so that conscience and justice slip away from faith.

\section{Wrestling with Matthew}

It is naive and dangerous to consider the biblical texts's patriarchy as somehow less oppressive, that a subdued form makes it more humane. Furthermore, superficial readings of biblical texts just to make them acceptable to contemporary needs are just as unacceptable. There is also a third possibility, the easy one: to claim that a proper use of Matthew is irrelevant to such an important issue. We need to be more responsible and find a better, but obviously more complex alternative.

We focus here on Matthew, and this text is simply part of its androcentric world - as much part of it as it is part of a pre-industrial, non-nuclear world. Gender issues were not his concern. But given his own theology, it could have been, and should become one of major importance. More critically, given that we no longer share Matthew's world, we are faced with the question whether collegiality (without explicit gender critical awareness) is a good enough response to God and to the world; whether collegiality and the maintenance of the patriarchal household values really are being the salt of the earth and the light on top of the stand? However, possible disagreement presupposes that Matthew could have conceptualised different social structures.

\subsection{Historical possibilities}

Various possible alternatives could have been considered by Matthew.

No doubt the worldview and symbolic universe of first-century Mediterranean societies had a severe and limiting impact on understanding women and the development of gender freedom. One needs only recall concepts with regard to physiology 13 , the hierarchical ethos (cf. Botha, 2000:18-21) and the lack of science and technology ${ }^{14}$. It is therefore particularly remarkable that various groups did attempt to transcend conventional gender stereotypes.

13 The one-sex model dominated views on human anatomy and bodiliness. See Laqueur (1990:10, 25-35), Lloyd (1983:94-111).

14 Since the second half of the twentieth century, for instance, technology contributed to the empowerment of women by means of effective birth control. 
Obviously, the first comment relates to the history of daily life. No ideology is lived out in perfection:

... it is important to keep in mind that a multitude of prohibitions mostly implies that the forbidden things did indeed take place. To put it another way: when it is so explicitly and emphatically prohibited that women receive or give formal education, that women move in public outside their homes, that women speak with men, that women have leading positions etc., then that certainly implies that these things did happen. Where there is smoke there is fire. Where there are strong prohibitions, there are usually a great many 'transgressions' (Van der Horst, 1994:80).

In the light of this Matthew's complete lack of reference to exactly such "small" resistances in his communities becomes suspect. Be that as it may, for our purpose here we need to look at more formalised gender role alternatives.

As is well-known, a number of Jewish temples existed in the Diaspora: at Arad, Elephantine, Araq el-Emir and at Leontopolis (Stone, 1980:77-81). The temple at Leontopolis (Tell el-Yahudiyyeh, Egypt) functioned as a cultic centre from 160 BCE until $73 \mathrm{CE}$, and is the best documented. An inscription from Leontopolis, dated 7 June 28 BCE, refers to "Marion, priestess [í́pı $\sigma \sigma \alpha]$ ]" (Corpus Inscriptionum Judaicarum 1514). Possibly the Jews of Leontopolis, living in a land where women priests were acceptable, saw the cultic participation of Jewish women as natural (cf. Brooten, 1982:88). The implication of this inscription is enhanced by the fact that we have some 20 inscriptions, all from the Diaspora, that mention women as head of the synagogue, or as elders or mother of the synagogue (Van der Horst, 1991:105-109). These inscriptions show that in "some diaspora situations women could rise to high positions and even leadership in Jewish communities" (Van der Horst, 1991:108).

Philo of Alexandria describes a monastic type of Judaism which practised celibacy in various parts of Egypt. It had both male (Therapeutae) and female (Therapeutrides) members who had left the cities to follow a contemplative life (Philo: De vita contemplativa 32-33, 68-69). This movement offered a clear means of bypassing the norms of patriarchy, allowing an alternative form of existence for women.

In several contemporary Jewish traditions women are depicted as models; witness the Book of Judith and a number of stories in the rabbinic haggadah. ${ }^{15}$

15 See, for examples, Judith 7:19-32; 8:11-36; 14:1-7; y.Sota 1:4; y. Horayot 3:4; b. Ta'anit $23 a b$. 
To these glimpses of alternatives should be added the role of women in the Pauline movement and in some early churches. Among several of the early Christian groups of the late first and second centuries rethinking of gender roles progressed both formally by means of the institution of deaconesses and the development of the order of widows (Schoedel, 1985:252) and informally by allowing social freedom to a limited extent (Osiek, 1998:312-315). Confirmation of this can be seen in the many early Christian (idealised) prescriptions (not descriptions) of women's roles in the writings of male church leaders (cf. Schüssler Fiorenza, 1983:309-310). Some early Christian groups did allow women to teach and participate fully in their activities (Schüssler Fiorenza, 1983:313; Elm, 1994) although more common was women teaching women (Osiek \& Balch, 1997:167-173).

\subsection{A vision of God}

Basic to the Gospel of Matthew are the convictions that God has created the world and sustains it at each moment, that God has made himself16 known, that God's will has been proclaimed to Israel's forebears and preserved by the covenant people in the Scriptures (the "words" of the ancestors). He is the "living God" who has chosen his people to do his will $(6: 33 ; 7: 21 ; 12: 50 ; 25: 37 ; 46)$. Matthew summons the "people of God" not to deny their ancient faith or to abandon their ancient obligations, but to accept the good news that the reign of heaven is at hand and, in view of that reality, to rightly understand and rightly observe that divine will which God's people have already been given, though not in its final, "fulfilled" form. To Matthew God is not just creator, but the judge of justice and righteousness.

With this vision comes an encounter; a confrontation brought about by the teaching and activities of Jesus ("Repent, for the reign of heaven is at hand", 4:17; 10:7). At the heart of Matthew's vision lies a division. What this division entails is illustrated by the parables about the "secrets of the reign of heaven" (Matt. 13:1-52). ${ }^{17}$ The evangelist is here dealing with the response God's word receives when it is proclaimed by Jesus and his messengers. This "word" divides its hearers into two categories: some receive it and then act upon it by living accordingly ("hears ... and understands ... bears fruit", 13:23); others reject or are only superficially

16 Obviously Matthew used male pronouns to refer to God. This presents us a further indication of how pervasive the androcentric ideology is. Like many ancient thinkers (esp. Jewish and early Christian), Matthew probably did not perceive God in terms of sexuality, but of gender.

17 The central role of Mattew 13 in the narrative is shown by Vorster $(1977 ; 1985)$; useful exegesis by Gerhardsson (1967; 1973). 
and temporarily receptive. Consequently, Matthew emphasises, "those who have" [the "word"] become "richer", to the point of overflowing ( $\pi \epsilon \rho \iota \sigma \sigma \epsilon v \theta \eta \dot{\eta} \sigma \epsilon \tau a \iota, 13: 12$ ), yielding a hundredfold (sixtyfold, thirtyfold) in harvest. "Those who do not have" [the "word"] will lose even the little they may have had. They do not act, they are not righteous (cf. 13:43). The word of God's reign is proclaimed in vain to those who do not love with their whole heart (cf. 13:9) with their whole life (cf. 13:21) and with all their strength (13:22).

What the overflowing abundance of those who bear rich fruit consists of is treated clearly and in detail in Matthew 5:17-48. The reign of heaven demands righteousness that exceeds in comparison with that of the scribes and Pharisees (5:20, $\pi \epsilon \rho \iota \sigma \sigma \epsilon \dot{v} \epsilon \iota \nu$ again!). Matthew 5 makes very, very clear that righteousness must be "overflowing", abundantly overflowing to "hear and understand" the word of the reign of heaven. The statements of the Matthean Jesus sharpen what is demanded by conventional ethics and prompt an attitude which goes infinitely further. "You, therefore, must be perfect, as your heavenly Father is perfect" $(5: 48)$.

In the discourse in Matthew 23 the same emphasis is developed further. In verses 2-3 loyalty and obedience toward the demands made by those occupying "Moses' seat" are decreed. Promptly, however, the Matthean Jesus subject these authorities, the scribes and Pharisees, to a blistering critique for their insensibility toward what is more and what is less important - what is "overflowing righteousness" and what not. What is demanded first of all is an observance of the "weightier matters of the law, justice, and mercy [= love for one's neighbour] and faithfulness" ( $T \grave{a}$

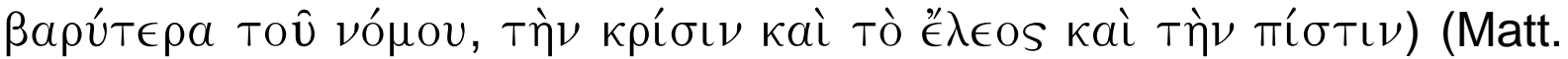
23:23). Reference could also be made to Matthew 12:1-12 and 15:1-20, but these themes pervade Matthean theology. At the core of Matthew's vision is the conviction that concrete commands are much too imperfect an indication of what God requires. Conventional ethical and religious prescription (Matthew makes no distinction between morality and faith) must be radicalised into overflowing righteousness.

Matthew's version of the "greatest command" emphasises insight.18 Why the emphasis on "mind" or understanding ( $\delta$ cá $\nu$ ola)? There is a second commandment, which is "like it", that is, like the "first and great commandment" (22:38-39). To love God is "like" loving one's neighbour. And reading Matthew one could easily get the impression that what God demands is exclusively concern for fellow humans, and that the

18 Mattew 22:34-40. Matthew changes Mark's version in two important aspects: he

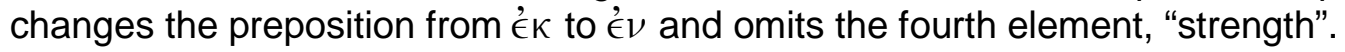


relationship to the heavenly Father is among those things which may be allowed to fall away $(7: 12 ; 19: 6-23 ; 25: 31-46$, for example). This is exactly what Matthew's "understanding" entails. Love of God is overflowing obedience, justice, love, righteousness.

\subsection{Beyond evenness: Justice and overflowing righteousness}

It is clear that neither gender roles nor female leadership were topics that interested Matthew. It is also probably true that he preferred not to conceive of such problems, despite the observable developments in early Christianity. But we are not in Matthew's position and most definitely no longer part of his first-century community.

Given his own religious and ethical vision, we realise that the goal of "collegiality" (at best) is simply not good enough. That Matthew does not carry his own vision into the world of gender can and should be made an issue. The Matthean text will not drive us to gender equality and rules. But what his narrative does do is to drive us to justice and overflowing righteousness.

In that sense we can claim Matthew for more than just gender equality; from Matthew we gain inspiration for gender freedom. Not just equity, but empowerment. Not a mere "love patriarchalism" but a life of service (by men as well) that liberates (all), that truly reveals the "weightier" matters of the law.

\section{Scripture in a changing world}

Wrestling with Matthew, and even arguing with him, raises the question of Scripture and "authority". To appreciate both the magnitude and significance of the dilemmas at stake a brief review of feminist hermeneutical responses to the "thoroughly androcentric and patriarchal" nature of the Bible (Anderson, 1991:23-24) will aid us. To simplify matters somewhat, three basic programmes can be identified.

- The rejectionist approach eschews any use of the Bible as hopelessly patriarchal (cf. Daly, 1985 [1973]). The criticism in this approach should be taken deeply serious by persons who emphasise memory and identity, or commitment to the Christian tradition.

- The revisionist approach is probably best represented by Phyllis Trible (1978; 1984): the biblical tradition is worth rehabilitating. Admittedly, such exegeses attacks the symptoms, rather than the system of patriarchy that has denied/suppressed women's freedom.

- The liberation approach shares the confidence of the revisionist model, but focuses more explicitly on the central message of the Bible, 
liberation. Where that message is found, God speaks. The liberationist model is exemplified by Elisabeth Schüssler Fiorenza, among many others.

Though my own sympathies lie with the liberationists, one must note the possible biblicism inherent in both the revisionist and liberationist projects. Even when the misogynistic parts and problematic aspects of biblical tradition are acknowledged, there is still the impression of "rescuing" the Bible in the revisionist and liberationist models: that some "methodology" can "save" Scripture.19 Or some other location for divine authority can be found ("original" or "true" history; or a canon within the canon). The task of reconstituting the historical and literary universes relating to women of the Bible is (and will remain) a most important task, yet one cannot but admit that after every hint in Scripture of the historical role of women in biblical times has been tracked down, and every story involving women characters has been explicated, the sum total will still be only one coin in ten, and "the other nine coins of patriarchy seem overwhelming. ... When all the recovery is done, is it enough to live with?" (Tolbert, 1983:124).

Given the importance of Scripture for memory and identity and the relevance of feminist hermeneutics, but also acknowledging that mere biblicism solves nothing, I propose that it is time that we accept responsibility for what we do when we read Scripture.

It is not the biblical text which moves into the future. That is irrevocably lodged in the past. What moves into the future is the church. As Driver (1981:83) observes, it is required of us to acknowledge that:

The authority of the Bible emerges within, and not prior to, our experience of the present world and its possible future. ... The authority of Jesus and of scripture for Christians does not stand by itself: it is one part of the complexity of our ethical life, and the churches would be more credible if they frankly said so. We should not ask what the Bible 'tells' us, but how it helps, and also hinders, our collaboration with God.

Exactly by moving beyond biblicism we realise that it is the latent sexism of readers of the Bible which motivates persons to use Scripture to justify opposition to the participation of women in ministry and so forth. The persistent unwillingness to deal with the Bible's androcentrism and patriarchy, uncritical biblicism to name it clearly, inhibits the church from

19 It is noteworthy that descriptions such as "deconstructing", "re-interpretation", "multiple readings", "reader-response criticism" (and many others) dominate feminist hermeneutics. 
shaping a response to our own context and unnecessarily limits our theological resources.

It is best to conceive of God's Word in a dynamic sense (cf. Botha, 1998). The "Word of God" is something that happens, it is a meeting, an event and not a thing. This may happen when the Bible is studied, but not any and all reading of the Bible can be God speaking. "Word of God" can only take place in the process of interpretation, and all interpretation is language and culture bound. It has always been so - also for the authors of the biblical books. Where one comes from, where one finds oneself, which discourse and insights are available to one, all becomes part of the meeting/confrontation/interpretive event: subtly (and sometimes not so subtly) but completely interwoven with the "Word of God". Without the Bible Christians do not want to speak about the Word of God, but we cannot do so without a worldview, a culture or even a body.

Critical reflection is simply part of the process of understanding. Rethinking of, and even disillusionment with, biblical actualities are not stumbling blocks but building blocks. God's truth is not something "out there", an objective thing to be found by accident, but something that comes into being between people studying Scripture and tradition, and it develops by means of conversation, analysis and knowledge.

Consequently I would urge that we conceive of revelation as a process of sufficient breadth that it embraces not only the Bible and church tradition, but contemporary scholarship and moral reflection as well. Such an approach would be open to the radical critique of the Bible, but will also draw on the larger theological resources of the church and intellectual life at the same time. Most of all, it will operate with a vision of the life before God (such as Matthew's overflowing righteousness). Such a hermeneutic could avail itself of the insights achieved by liberationists and avoid the pernicious biblicism that plagues their critics.

To confront the question of authority we need to acknowledge a task which is larger than the interpretation of Scripture. Tom Driver (1981:9091) provides apt insight:

The church, broadly speaking, is the author of scriptures, and from this their authority proceeds. Certainly the church is the body that authorized the Christian canon and still today maintains it. This is what we must own up to. Doing so would free us to ask what good the scriptures are for us in the liberating work we are called to share with God in the present-future. It would also free us to see more clearly, and with less rationalization, the scripture's liabilities. Finally, and most threateningly, such ownership of authorship would make the church clearly political, for its reality would then be understood as 
the way it acts upon the present scene. As long as scripture is viewed as a purely external authority derived from past time, it circumvents responsibility for present action, no matter if the Bible itself calls us to responsibility. But the moment we view the Bible as something we have written, for the purpose of not forgetting the encounters we have had with God, our identity becomes more clear and we may be agents in the new work God performs today.

Scripture as revelation is a process. In the very confrontation with Matthew's own theology lies the challenge to develop it and apply it more consistently.

A proper hermeneutic is not to prove those who found patriarchy in Scripture wrong, but to prove those wrong who drew authority from those readings. If gender privileging is wrong on religious grounds, it is wrong not because the Bible tells us so, but because one believes God tells us so. And then it is wrong wherever we find it. To paraphrase Karl Marx, the challenge is not to interpret the text in various ways, but to change the interpreter, to change our world. 20

\section{Concluding remarks}

The urgency and seriousness of women's issues and feminist challenges should not lead to deliberate forcing of biblical texts. The Bible will always remain a challenge for Christians to provide identity, memory and direction, and that challenge demands careful, responsible reflection.

By acknowledging that Matthew is not primarily concerned with women, and even less with gender roles, frees us to notice what is of importance to him: Gentiles becoming part of "true Israel", and that true "Israel" loves God by means of overflowing righteousness.

\section{Bibliography}

ANDERSON, J.C. 1983. Matthew: gender and reading. Semeia, 28:3-27.

ANDERSON, J.C. 1991. Mapping feminist biblical criticism: the American scene, 1983-1990. (In Epp, E.J., ed. Critical review of books in religion. Atlanta : Scholars Press. p. 21-44.)

BATTEN, A. 1994. More queries for Q: women and Christian origins. Biblical Theology Bulletin, 24:44-51.

BOTHA, P.J.J. 1998. History, Scripture and revelation: a conversation with Ferdinand Deist. Old Testament Essays, 11(3):386-414.

BOTHA, P.J.J. 2000. Submission and violence: exploring gender relations in the first century world. Neotestamentica, 34(1):1-38.

20 The reference is to Marx's "Theses on Feuerbach". See Marx (1983:158). 
BROOTEN, B.J. 1982. Women leaders in the ancient synagogue: inscriptional evidence and background issues. Atlanta : Scholars Press.

BROWN, R.E. 1977. The birth of the Messiah: a commentary on the infancy narratives in Matthew and Luke. London : Chapman.

CARTER, W. 1996. Matthew: storyteller, interpreter, evangelist. Peabody : Hendrickson.

CRAFFERT, P.F. 1996. Reading and divine sanction: the ethics of interpreting the New Testament in the new South Africa. (In Porter, S.E. \& Olbricht, T.H., eds. Rhetoric, Scripture and theology: essays from the 1994 Pretoria Conference. Sheffield : Sheffield Academic Press. p. 54-71.)

CRAFFERT, P.F. 2001a. Jesus van Nasaret as historiese figuur: Die rol van wêreldbeelde en interpretasiestyle. Fragmente, 7:101-115.

CRAFFERT, P.F. 2001b. Vernuwing in historiese Jesus-navorsing. Verbum et Ecclesia, 22(1):1-29.

CROSBY, M.H. 1988. House of disciples: church, economics, and justice in Matthew. Maryknoll : Orbis.

DALY, M. 1985 [1973]. Beyond God the Father: toward a philosophy of women's liberation. Boston : Beacon Press. (Original work published in 1973.)

DANKER, F.W. 1994. Matthew: a patriot's gospel. (In Evans, C.A. \& Stegner, W.R., eds. The Gospels and the Scriptures of Israel. Sheffield : Sheffield Academic Press. p. 94-115.)

DAVIES, S. 1991. Women in the Third Gospel and the New Testament apocrypha. (In Levine, A.-J., ed. "Women like this": new perspectives on Jewish women in the Greco-Roman world. Atlanta : Scholars Press. p. 185-197.)

DRIVER, T.F. 1981. Christ in a changing world: toward an ethical Christology. New York : Crossroad.

ELLIOTT, J.H. 1981. A home for the homeless: a sociological exegesis of 1 Peter, its situation and strategy. Philadelphia : Fortress.

ELM, S. 1994. Montanist oracles. (In Schüssler Fiorenza, E., ed. Searching the Scriptures. Vol. 2: a feminist commentary. New York : Crossroad. p. 131-138.)

GARNSEY, P. \& SALLER, R. 1987. The Roman empire: economy, society and culture. Berkeley : University of California Press.

GASTON, L. 1975. The messiah of Israel as teacher of the gentiles: the setting of Matthew's christology. Interpretation, 29:24-40.

GERHARDSSON, B. 1967. The Parable of the Sower and its interpretation. New Testament Studies, 14:165-193.

GERHARDSSON, B. 1973. The seven parables in Matthew XIII. New Testament Studies, 19:16-37.

GERHARDSSON, B. 1974. Sacrificial service and atonement in the gospel of Matthew. (In Banks, R., ed. Reconciliation and hope. Exeter : Paternoster. p. 25-35.)

JUDGE, E.A. 1960. The social pattern of Christian groups in the first century. London : Tyndale.

KINGSBURY, J.D. 1977. Matthew: a commentary for preachers and others. Proclamation Commentaries. Philadelphia : Fortress.

KINGSBURY, J.D. 1978. The verb akolouthein ("to follow") as an index of Matthew's view of his community. Journal of Biblical Literature, 97:56-73.

KOPAS, J. 1990. Jesus and women in Matthew. Theology Today, 47:13-21.

LAQUEUR, T.W. 1990. Making sex: body and gender from the Greeks to Freud. Cambridge (M): Harvard University Press. 
LLOYD, G.E.R. 1983. Science, folklore and ideology: studies in the life sciences in ancient Greece. Cambridge : Cambridge University Press.

LOADER, W.R.G. 1982. Son of David, blindness, possession, and duality in Matthew. Catholic Biblical Quarterly, 44:570-585.

LOVE, S.L. 1993. The household: a major social component for gender analysis in the Gospel of Matthew. Biblical Theology Bulletin, 23(1):21-31.

LUZ, U. 1995. The theology of the Gospel of Matthew. Cambridge : Cambridge University Press.

MACMULLEN, R. 1974. Roman social relations: 50 B.C. to A.D. 284. New Haven : Yale University Press.

MALHERBE, A.J. 1983. Social aspects of early Christianity, 2d ed. Philadelphia : Fortress.

MARX, K. 1983. The portable Karl Marx. (E. Kamenka, ed. and trans.). New York : Penguin.

MEIER, J.P. 1979. The vision of Matthew: Christ, church and morality in the first gospel. New York : Paulist Press.

OSIEK, C. \& BALCH, D.L. 1997. Families in the New Testament world: households and house churches. Louisville : Westminster John Knox Press.

OSIEK, C. 1998. Women in the house churches. (In Hills, J.V., ed. Common life in the early church. Harrisburg : Trinity Press International. p. 244-257.)

REINHARTZ, A. 1991. From narrative to history: the resurrection of Mary and Martha. (In Levine, A.-J., ed. "Women like this": new perspectives on Jewish women in the Greco-Roman world. Atlanta : Scholars Press. p. 161-184.)

SALDARINI, A.J. 1994. Matthew's Christian-Jewish community. Chicago : University of Chicago Press.

SCHABERG, J. 1992. Luke. (In Newsom, C.A. \& Ringe, S.H., eds. The women's Bible commentary. Louisville : Westminster/John Knox. p. 275-292.)

SCHOEDEL, W.R. 1985. Ignatius of Antioch: a commentary on the Letters of Ignatius of Antioch. Philadelphia : Fortress.

SCHOTTROFF, L. 1993. Women as followers of Jesus in New Testament times: an exercise in sociohistorical exegesis of the Bible. (In Gottwald, N.K. \& Horsley, R.A., eds. The Bible and liberation: political and social hermeneutics. Maryknoll : Orbis. p. 453-461.)

SCHÜSSLER FIORENZA, E. 1979. The study of women in early Christianity: some methodological considerations. (In Ryan, T.J., ed. Critical history and biblical faith: New Testament perspectives. Villanove : College Theology Society. p. 3058.)

SCHÜSSLER FIORENZA, E. 1983. In memory of her: a feminist theological reconstruction of Christian origins. New York : Crossroad.

SCHÜSSLER FIORENZA, E. 1993. The practice of biblical interpretation: Luke 10:38-42. (In Gottwald, N.K. \& Horsley, R.A., eds. The Bible and liberation: political and social hermeneutics. Maryknoll : Orbis. p. 172-197.)

SCHÜSSLER FIORENZA, E. 1994. Miriam's child, Sophia's prophet. Maryknoll : Orbis.

SELVIDGE, M.J. 1984. Violence, woman, and the future of the Matthean community: a redactional critical study. Union Seminary Quarterly Review, 39:213-223.

SENIOR, D. 1975. The passion narrative according to Matthew. Louvain : Leuven University Press.

STONE, M.E. 1980. Scriptures, sects and visions: a profile of Judaism from Ezra to the Jewish revolts. Cleveland: Collins. 
TOLBERT, M.A. 1983. Defining the problem: the Bible and feminist hermeneutics. Semeia, 28:113-126.

TRIBLE, P. 1978. God and the rhetoric of sexuality. Philadelphia : Fortress.

TRIBLE, P. 1984. Texts of terror: literary-feminist readings of biblical narratives. Philadelphia : Fortress.

VAN DER HORST, P.W. 1991. Ancient Jewish epitaphs: an introductory survey of a millennium of Jewish funerary epigraphy (300 BCE - $700 \mathrm{CE})$. Kampen : Kok Pharos.

VAN DER HORST, P.W. 1994. Hellenism - Judaism - Christianity: essays on their interaction. Kampen : Kok Pharos.

VERNER, D.C. 1983. The household of God: the social world of the Pastoral Epistles. Chico : Scholars Press.

VORSTER, W.S. 1977. The structure of Matthew 13. Neotestamentica, 11:130-138.

VORSTER, W.S. 1985. Gelykenisse in konteks. Matteus 13 en die gelykenisse van Jesus. Hervormde Teologiese Studies, 41:148-165.

WILKEN, R.L. 1971. Collegia, philosophical schools, and theology. (In Benko, S. \& O'Rourke, J.J., eds. The catacombs and the Colosseum: the Roman empire as the setting of primitive Christianity. Valley Forge : Judson. p. 268-291.)

WIRE, A.C. 1991. Gender roles in a scribal community. (In Balch, D.L., ed. Social history of the Matthean community: cross-disciplinary approaches. Minneapolis : Fortress. p. 87-121.)

\section{Key concepts:}

gender equality

Gospel of Matthew

patriarchy

righteousness

use of Scripture

Kernbegrippe:

Evangelie van Matteus

geregtigheid

geslagsgelykheid

patriargie

Skrifgebruik 